\title{
Examining ISIS Online Recruitment through Relational Development Theory
}

\section{Sarah Ponder ${ }^{a}$ and Jonathan Matusitz ${ }^{b}$}

a Nicholson School of Communication, University of Central Florida, https://communication.ucf.edu/

b Nicholson School of Communication, University of Central Florida, Partnership Center - Seminole State College of Florida, https://www.seminolestate.edu/s/m/university-partnership-center

\begin{abstract}
This paper applies the theory of relational development to examine how the Islamic State of Iraq and al-Sham (ISIS) recruits new members. Relational development postulates that individuals follow relationship stages in order to reinforce their interpersonal communication or social bond. The relational development model includes five main stages, called the five stages of relationship escalation, or the "coming together" stages. These consist of initiating, experimenting, intensifying, integrating, and bonding. Overall, the authors of this analysis found that ISIS can successfully recruit many people-particularly male and female youth-thanks to stage-by-stage relational development through internet chat rooms and social network sites (SNSs) like Twitter. By the same token, the authors also believe that, should ISIS not use internet chat rooms and social network sites, and if ISIS were not following those stages of relationship escalation, their recruitment process would not be as efficient.
\end{abstract}

Keywords: caliphate, Internet, ISIS, radicalization, relational development, social media, terrorism. Twitter.

\section{Introduction}

This paper applies the theory of relational development to examine how the Islamic State of Iraq and al-Sham (ISIS) recruits new members. ISIS is a powerful Islamist terrorist organization responsible for perpetrating a high number of violent attacks on innocent civilians in regions like the Near East. ISIS believes in 
establishing a caliphate (an Islamic system of world government). Relational development postulates that individuals follow relationship stages in order to reinforce their interpersonal communication or social bond. ${ }^{1}$ The relational development model includes five main stages, called the five stages of relationship escalation, or the "coming together" stages. These consist of initiating, experimenting, intensifying, integrating, and bonding. ${ }^{2}$ Initiating is the stage in which an individual makes contact with another individual. Experimenting occurs when one seeks to know more about someone and determines whether or not to continue a relationship. Intensifying occurs when individuals are more comfortable in an interpersonal dialogue and share much more personal details. Integrating occurs when people begin to identify themselves together or as a part of the same group. And bonding is a public allegiance and full-fledged commitment to a group.

Overall, the authors of this analysis found that ISIS can successfully recruit many people-particularly male and female youth-thanks to stage-by-stage relational development through internet chat rooms and social network sites (SNSs) like Twitter. By the same token, the authors also believe that, should ISIS not use internet chat rooms and social network sites (SNSs), and if ISIS were not following those stages of relationship escalation, their recruitment process would not be as efficient. This analysis begins with a detailed description of the theory of relational development (based on all five stages). Then, the authors proceed to describe ISIS and its overall recruitment methods. What comes subsequently is the heart of this analysis: the examination of ISIS recruitment through relational development. This analysis ends with a discussion that also includes suggestions for future research.

\section{Relational Development Theory}

Developed by Knapp, ${ }^{3}$ the theory of relational development explains how interactants-e.g., couples, negotiators, and so forth-follow relationship stages so as to reinforce their interpersonal communication or social bond. The theory postulates that relationships evolve into stages as a result of interpersonal dialogue. Such dialogue sheds light on the interactants' positive or negative experiences and modifications of their intimacy or communication styles. ${ }^{4}$ Relational

1 Mark L. Knapp, Social Intercourse: From Greeting to Goodbye (Boston, MA: Allyn and Bacon, 1978); Mark L. Knapp, Interpersonal Communication and Human Relationships (Boston, MA: Allyn and Bacon, 1984).

2 Mark L. Knapp and John A. Daly, eds., Handbook of Interpersonal Communication, 3rd ed. (Thousand Oaks, CA: Sage, 2002).

3 Knapp, Social Intercourse; Knapp, Interpersonal Communication and Human Relationships.

4 Theodore A. Avtgis, Daniel V. West, and Traci L. Anderson, "Relationship Stages: An Inductive Analysis Identifying Cognitive, Affective, and Behavioral Dimensions of Knapp's Relational Stages Model," Communication Research Reports 15, no. 3 (1998): 280-287. 
development also rests on the premise that "relationships evolve into stages as a result of interpersonal dialogue." 5 The relational development model includes five main stages, called the five stages of relationship escalation, or the "coming together" stages. These consist of initiating, experimenting, intensifying, integrating, and bonding. ${ }^{6}$ Although relationship escalation entails cycles of growing together, this would not work for relationships that are disintegrating. ${ }^{7}$

\section{Initiating}

When developing relationships, unacquainted people start to have intentions, hopes, needs, desires, wishes, and beliefs in mind in order to guide their actions. ${ }^{8}$ The first stage of relationship escalation or "coming together" is initiating: the stage in which an individual makes contact with another individual. At this stage, people acknowledge each other and start to share discourses. This stage is important because the first elements of knowledge about an individual, called "first impression," are formed in it. ${ }^{9}$ The concept of first impression has an intense impact on relational development: it influences the opinion about the quality of a person, often determines the destiny of a relationship (whether or not it will last), and persists for a long time in the mind of the other interactant - hence, the better the first impression, the more positive it will be perceived. Even though the impact of the first impression can be profound, it can be created within a fraction of a second, based mostly on how a person communicates or the external and physical traits of that person, such as his or her physical appearance, body language, and attire. ${ }^{10}$

\section{Experimenting}

According to Fox, Warber, and Makstaller, experimenting occurs when one seeks to know more about someone and determines whether or not to continue a

5 Jonathan Matusitz, Terrorism and Communication: A Critical Introduction (Thousand Oaks, CA: Sage, 2012), quote on p. 365.

6 Knapp and John A. Daly, eds., Handbook of Interpersonal Communication.

7 Daniel J. Canary, Michael J. Cody, and Valerie L. Manusov, Interpersonal Communication: A Goals Based Approach, 4th ed. (New York: Bedford/St. Martin's, 2008).

8 Dorothy Miell and Steve Duck, "Strategies in Developing Friendships," in Friendship and Social Interaction, ed. Valerian J. Derlega and Barbara A. Winstead (New York: Springer, 1986), 129-143.

9 Michael Sunnafrank and Artemio Ramirez, Jr., "At First Sight: Persistent Relational Effects of Get-Acquainted Conversations," Journal of Social and Personal Relationships 21, no. 3 (2004): 361-379.

10 Christopher Y. Olivola and Alexander Todorov, "Elected in 100 milliseconds: Appearance-Based Trait Inferences and Voting," Journal of Nonverbal Behavior 34, no. 2 (2010): 83-110. 
relationship. ${ }^{11}$ This stage commonly occurs shortly after the initiating phase. In the experimenting phase, people aim to gather information on one another by asking questions. They look for common interests through limited self-disclosure, while correcting possible mistakes made during the first impression (formed in the previous initiating stage). The knowledge exchanged in this stage includes personal interests. ${ }^{12}$

Experimenting is a probing stage in which people make a further evaluation of each other, which is what Knapp terms "trying to discover the unknown."13 Welch and Rubin state that "communicators explore commonalities and generally increase breadth of topics, rarely delving into specific ones." ${ }^{14}$ Small talk is highly representative of this stage as it gives interactants the possibility to reveal more details about each other and expand the current scope of the relationship. Knapp indicates that, at this stage, the relationship places limited demands on the interactants. ${ }^{15}$

\section{Intensifying}

Intensifying occurs when individuals are more comfortable in an interpersonal dialogue. Fox et al. found that people often disclose more information during the intensifying phase; relationships, then, beginning to appear. ${ }^{16}$ At this stage, the relationship status between individuals is labeled "close friends." Interaction has more self-disclosure (e.g., revealing more personal information) and intimate verbal and nonverbal actions (use of nicknames and compliments), informal speech, asking for favors, and so forth. ${ }^{17}$ More direct expressions of commitment emerge. In a nutshell, interpersonal intimacy is finally formed: increased depth of disclosure is now happening and communication acknowledges the friendship that has developed. ${ }^{18}$

11 Jesse Fox, Katie M. Warber, and Dana C. Makstaller, "The Role of Facebook in Romantic Relationship Development: An Exploration of Knapp's Relational Stage Model," Journal of Social and Personal Relationships 30, no. 6 (2013): 771-794.

12 Paul A. Mongeau and Mary Lynn Miller Henningsen, "Stage Theories of Relationship Development: Charting the Course of Interpersonal Communication," in Engaging Theories in Interpersonal Communication: Multiple Perspectives, ed. Leslie A. Baxter and Dawn O. Braithwaite (Thousand Oaks, CA: Sage, 2008), 363-375.

13 Knapp, Social Intercourse, p. 21.

14 S-A Welch and Rebecca B. Rubin, "Development of Relationship Stage Measures," Communication Quarterly 50, no. 1 (2002): 24-40, quote on p. 25.

15 Knapp, Interpersonal Communication and Human Relationships.

16 Fox, Warber, and Makstaller, "The Role of Facebook in Romantic Relationship Development."

17 Denise Haunani Solomon and Anita L. Vangelisti, "Relationship Development," in Interpersonal Communication, ed. Charles R. Berger (Berlin: De Gruyter Mouton, 2014), 347-369.

18 Knapp, Social Intercourse: From Greeting to Goodbye. 


\section{Integrating}

Integrating occurs when people begin to identify themselves together or as a part of the same group. At this stage, tightly-knit groups emerge. The term "coupling" can be applied here: people start appearing similar (nonverbally) and think of themselves as friends. ${ }^{19}$ They are akin in terms of attitudes, interests, and opinions. The relationship is now private and persistent: intimate information and secrets are frequently shared, and individuals exchange aspects of their social identity (e.g., in regards to friends, family, and living spaces). ${ }^{20}$ People also "wear" each other's identity through intimate tokens. For example, through pictures and pins, they have reached a higher synchronicity in behavior. ${ }^{21}$

\section{Bonding}

The bonding stage occurs when people start to identity with an individual or a group publicly. At this stage, the close relationship is represented by a formal, public commitment to the relationship or group affiliation-e.g., through a formal pledge, ceremony, or ritual-and the utmost level of empathy, trust, and intimacy. ${ }^{22}$

\section{Islamic State of Iraq and al-Sham (ISIS)}

Occasionally called the Islamic State of Iraq and the Levant (ISIL) in the media, or simply the Islamic State, the Islamic State of Iraq and al-Sham (ISIS) is an extremist Muslim-based terrorist organization that has control of large expanses of territory in Iraq and Syria, as well as smaller areas in African countries such as Libya and Nigeria. ISIS is also active in parts of the world including Southeast Asia. ${ }^{23}$ The roots of ISIS are based in Al Qaeda in Iraq (AQI), a terrorist group founded by Abu Musab al-Zarqawi, a Jordanian militant Islamist. In 2006, when Zarqawi was killed by U.S. and Iraqi forces, Abu Ayyoub al-Masri, an Egyptian, became the new leader, embracing the cause of what was then called the Islamic State of Iraq (ISI). In 2010, Abu-Bakr al-Baghdadi was announced as the newly proclaimed caliph - after the killing of Masri (the former leader), also by U.S. and

19 Welch and Rubin, "Development of Relationship Stage Measures."

20 Darius K.-S. Chan and Grand H.-L. Cheng, "A Comparison of Offline and Online Friendship Qualities at Different Stages of Relationship Development," Journal of Social and Personal Relationships 21, no. 3 (2004): 305-320.

21 Richard Moniz, Jo Henry, and Joe Eshleman, Fundamentals for the Academic Liaison (Chicago: American Library Association, 2014).

22 Mark L. Knapp and Anita L. Vangelisti, Interpersonal Communication and Human Relationships, 6th ed. (Boston, MA: Pearson Education, 2008).

23 Jay Sekulow, Jordan Sekulow, Robert W. Ash, and David French, Rise of ISIS: A Threat We Can't Ignore (Brentwood, TN: Howard Books, 2015); Ishaan Tharoor, "ISIS or ISIL? The Debate over What to Call Iraq's Terror Group," The Washington Post, June 18, 2014, p. A1. 
Iraqi forces. In April 2013, Al-Baghdadi renamed the organization the Islamic State of Iraq and al-Sham. ${ }^{24}$

ISIS vehemently believes in establishing a caliphate. A caliphate is a worldwide Islamic State, like an Islamic system of world government. ${ }^{25}$ This caliphate movement seeks to (1) revive the rule of the caliph (a supreme religious and political leader in Islam); (2) restore sharia (a body of Islamic law derived from the Qur'an and the hadiths) over both the ummah (the community of faithful Muslims) and non-Muslims all over the world; and (3) ultimately spread Islamic doctrine all over. ${ }^{26}$ In order to achieve the caliphate, ISIS says it has been called by Allah to carry out large-scale, coordinated attacks against both Muslims and nonMuslims. Terrorist attacks tend to involve suicide bombings, car bombs, mass executions, torture, and beheadings. ISIS terrorism is often displayed publically. This is the ultimate objective of terrorism: to intimidate audiences into supporting, or not resisting, ISIS's rapid conquest and control of the world. ISIS's capture of the city of Mosul (in northern Iraq) on June 10th, 2014 testifies to the organization's daunting military strength. ${ }^{27}$ The city of Mosul came to be considered ISIS's caliphate, or the Islamic State.

\section{ISIS Recruitment}

Today, ISIS is one of the fastest-growing, most violent, and wealthiest terrorist organizations in the world. ${ }^{28}$ ISIS firmly believes in the establishment of the caliphate and perpetrating jihad in the name of Allah. As Weiss and Hasan explain, "ISIS has destroyed the boundaries of contemporary nation-states and proclaimed itself the restorer of a lost Islamic empire." ${ }^{29}$ ISIS relies heavily on its strategic communication campaign. ISIS leaders have proven to excel in the use of online social media for recruitment and propaganda, both of which are critical to the success and growth of the organization. They are highly skilled in grabbing the attention of the Western world: through online videos they promote horrid imagery and brutality to be seen by both the ummah (the community of faithful

24 Zana Khasraw Gulmohamad, "The Rise and Fall of the Islamic State of Iraq and Al-Sham (Levant) ISIS," Global Security Studies 5, no. 2 (2014): 10-21.

25 Futoshi Matsumoto, "The World Order and a New "Behemoth"," Asia-Pacific Review 22, no. 1 (2015): 177-190.

26 Guy Rodgers, Understanding the Threat of Radical Islam (Broomall, PA: National Highlights, 2012).

27 Stansfield, "The Islamic State, the Kurdistan Region and the Future of Iraq: Assessing UK Policy Options," International Affairs 90, no. 6 (2014): 1329-1350.

28 Seongju Oh, Chaeyun Jung, and Taeseon Yoon, "Analysis of the Development of IS (Islamic State) in Its Relation to Conflicts within OIC (Organization of Islam Countries) by Using SPSS Statistical Program," International Journal of Social Science and Humanity 6, no. 10 (2016): 799-804.

29 Michael Weiss and Hassan Hassan, ISIS: Inside the Army of Terror (New York: Regan Arts, 2015), quote on p. 8. 
Muslims) and the non-Muslim world. ${ }^{30}$ While many view this brutality as grotesque, it unfortunately also projects the unprecedented power that ISIS possesses. $^{31}$

\section{ISIS and Social Network Sites (SNSs)}

There are three main narratives used by ISIS to appeal to its possible recruits. According to Gartenstein-Ross, the terrorist organization focuses mainly on the three following ideas: religious obligation, political grievances, and the success of the Islamic State. ${ }^{32}$ Regardless of gender and age, the most cited reason for joining ISIS is religious obligation or conviction. Many individuals are recruited online. Terrorist organizations also use prisons, religious institutions, and universities as recruitment grounds. Prisons in the Middle East have become much like academies for ISIS to recruit and train fighters. ${ }^{33}$ Foreign fighters, particularly those living outside the Islamic State, are most often recruited via propaganda through online strategic messaging, social media, and chat rooms. These techniques are often used for recruiting those who will not likely come in physical contact with ISIS fighters. ${ }^{34}$ According to Nissen, the main ISIS social media objectives are as follows:

- to bring attention to the caliphate message through social network sites (SNSs). SNSs give ISIS international attention

- raising financial support

- bringing together like-minded supporters

- recruiting and converting new members. ${ }^{35}$

Twitter is a major communication campaign source for ISIS. Even though Twitter suspended 125,000 ISIS-related accounts in February 2016, ${ }^{36}$ ISIS is always able to circumvent "filters" and create other Twitter profiles. One of ISIS's successful SNS undertakings is a Twitter app called The Dawn of Glad Tidings, or just Dawn. The app is a real ISIS product promoted by talented SNS users. It serves to keep the world abreast on the terrorist organization's latest exploits or

30 C. Akça Ataç, "A Comparative Civilizational Reading for the Middle East and Turkey's New Role in It," Global Change, Peace \& Security 28, no. 1 (2016): 99-115.

31 Daveed Gartenstein-Ross, "Testimony to the Committee on Homeland Security and Governmental Affairs, United States Senate," in Jihad 2.0: Social Media in the Next Evolution of Terrorist Recruitment, S. Hrg. 114-438 (Washington, D.C.: U.S. Government Publishing Office, 2016), 12-21, https://www.hsdl.org/?abstract\& did=798565.

32 Gartenstein-Ross, "Testimony."

33 Weiss and Hassan, ISIS: Inside the Army of Terror.

34 Gartenstein-Ross, "Testimony."

35 Thomas Elkjer Nissen, "Terror.com - IS's Social Media Warfare in Syria and Iraq," Contemporary Conflicts 2, no. 2 (2014): 1-8.

36 Jessica Guynn and Elizabeth Weise, "Twitter Suspends 125,000 ISIL-related Accounts," USA Today, February 5, 2016, p. A1. 
imminent actions. ${ }^{37}$ Another well-known ISIS twitter account is called Islamic State Media, in which the organization brags about exterminating atheists, female drivers, Shia Muslims, the Kurds, and the Jews.

The organization sends out series of tweets to spread their messages and warnings, along with pictures. Like many individuals or groups whose goal is to increase followers, they have set up "fake" followers' accounts. This serves to motivate real followers to join their accounts. ${ }^{38}$ ISIS also employs the use of Facebook, Instagram, Skype, and YouTube. Such SNSs are typically used to engage in conversation with possible recruits. They develop an interpersonal dialogue with potential Muslim brothers and sisters. There are numerous videos online that spread ISIS's messages, goals, and rituals such as beheadings. This terrorist organization also publishes its own publication, Dabiq. To be more precise, Dabiq is a monthly online magazine (50-60 pages) that extolls the virtues of sharia and jihad and pays tributes to the martyrs who died in holy war. ${ }^{39}$ As Nissen explains, ISIS "utilizes techniques normally associated with political campaigning, e.g. by sounding out possible support through feedback on potential ideas, terms and graphics." 40 The group "campaigns" online by spreading awareness of its cause and organization via social media, articles, videos, and websites - all useful tools put to use so as to recruit individuals to join the fight.

\section{ISIS Recruitment of Females}

The youth is particularly targeted for recruitment by ISIS for several key reasons. After all, young recruits provide clean records and cultural acclimation that benefit leaders because they draw less suspicion. ${ }^{41}$ Another benefit of using youth is that, if caught by the authorities, they may receive lighter punishment because of their young age. While male youth have served as the primary target for recruitment, there has recently been a rise in female recruitment. ${ }^{42}$ Females are most commonly recruited in active online chat rooms and various SNSs. This is a much more convenient platform for recruitment in comparison with recruitment methods in the 1990s, when terrorist recruiters had to rely more on face-to-face interactions. ${ }^{43}$

37 J.M. Berger, "How ISIS Games Twitter," The Atlantic, June 16, 2014, p. A1.

38 Nissen, "Terror.com - IS's Social Media Warfare in Syria and Iraq."

39 Till F. Paasche and Michael M. Gunter, "Revisiting Western Strategies against the Islamic State in Iraq and Syria," The Middle East Journal 70, no. 1 (2016): 9-29.

40 Nissen, "Terror.com - IS's Social Media Warfare in Syria and Iraq," p. 3.

41 Seong Hun Yu and Omar Sultan Haque, "Vulnerabilities among Young Westerners Joining ISIS," The Brown University Child and Adolescent Behavior Letter 32, no. 2 (2016): 1-6.

42 Thomas R. McCabe, "A Strategy for the ISIS Foreign Fighter Threat," Orbis 60, no. 1 (2016): 140-153.

43 Mia M. Bloom, "In Defense of Honor: Women and Terrorist Recruitment on the Internet," Journal of Postcolonial Cultures and Societies 4, no. 1 (2013): 150-195. 
While many females feel compelled to join ISIS for religious reasons, there are scores of women influenced by personal wants and needs. As Sherwood contends, "some young women were offered financial incentives, such as travel expenses or compensation for bearing children by ISIS." ${ }^{44}$ These females are also typically promised acceptance, sisterhood, and love. Men often chat with these female recruits, developing a relationship with them. Once recruited, they are expected to marry and bear children to secure the future of the organization. ${ }^{45}$ There has been a dramatic rise in the travel of Western women, mostly European, to the Middle East. Unfortunately, many girls who are targeted and recruited are between the ages of 16 and 24, but girls as young as 13 have also been identified. ${ }^{46}$ As Thomas Samuel puts it,

these groups attract youths by exploiting their vulnerabilities and providing them with a sense of identity, belonging and cohesiveness. Over a period of time, in a troubled environment, these youth begins to define their identity with that of the group and its struggle. ${ }^{47}$

\section{A Solution to Youth's Identity Crisis}

A certain number of youths today-even those living in Europe and North America-have an identity crisis: they struggle with unemployment, despair, and what they perceive as social rejection. ${ }^{48}$ This makes them particularly ripe for ISIS recruitment. Young folks living in poverty are also a chief focus for ISIS. To these youths, ISIS seems to offer perspective, a sense of belonging and fraternity, and, of course, adventure, bravery, and martyrdom. ISIS-inspired jihad provides an unparalleled substitute for drugs and everyday crime, and an unconventional global movement with clear and straightforward rules. ${ }^{49}$ According to Stern, since the 9/11 terrorist attacks, a significant minority of Western youth have joined the jihadist movement as a result of feelings of humiliation. ${ }^{50}$ They feel

44 Harriet Sherwood, Sandra Laville, Kim Willsher, Ben Knight, Maddy French, and Lauren Gambino, "Schoolgirl Jihadist: The Female Islamists Leaving Home to Join Isis Fighters," The Guardian, September 29, 2014, p. A1.

45 Bloom, "In Defense of Honor: Women and Terrorist Recruitment on the Internet."

46 Sherwood et al., "Schoolgirl Jihadist."

47 Thomas Koruth Samuel, "The Lure of Youth into Terrorism," SEARCCT's Selection of Articles 2 (2011): 107-119, quote on p. 109, http://www.searcct.gov.my/publications/ our-publications?id=55.

48 Alex S. Wilner and Claire-Jehanne Dubouloz, "Homegrown Terrorism and Transformative Learning: An Interdisciplinary Approach to Understanding Radicalization," Global Change, Peace \& Security 22, no. 1 (2010): 33-51.

49 Rik Coolsaet, What Drives Europeans to Syria, and to IS? Insights from the Belgian Case (Brussels: Royal Institute for International Relations, 2015), http://www.egmontinstitute.be/what-drives-europeans-to-syria-and-to-is-insightsfrom-the-belgian-case/.

50 Jessica Stern, "Militant Groups: Beneath Bombast and Bombs, a Cauldron of Humiliation," Los Angeles Times, June 6, 2004, p. A1. 
that the West has overpowered them and purposefully humiliated them; leading them to take up arms and fight. Stern also points out that, for a holy war, jihadist groups need young people who feel humiliated and at a loss. ${ }^{51}$ Once these impressionable recruits appear, they become leaders who emerge and, in turn, take advantage of other fragile people. This is how ISIS befriends and recruits individuals so as to establish their loyalty to the group.

\section{Examining ISIS Recruitment through Relational Development Theory}

The theory of relational development is applied to the process by which ISIS recruits people around the world. More precisely, this analysis correlates five stages of relationship escalation to the efforts ISIS has made to gain support and followers. We dissect each stage of the theory and apply it to the way ISIS communicates with people around the world in an attempt to spread its propaganda and gain support. It is important to note that such ISIS recruitment model takes places not only in the Middle East but also in the Western world. ${ }^{52}$

\section{Initiating}

The initiating phase is arguably the most important phase: the communicative aspect of recruitment has just begun. The recruiter or sympathizer makes contact with an individual or possible recruit. At this phase, people acknowledge each other and start to share discourses. Today, it has become more common to initiate discourses online through SNSs - rather than in person in a face-to-face setting. Through online chat rooms, Facebook, and Twitter, ISIS runs websites and magazines that all play a role in making a positive "first impression."

Dabiq, the ISIS-run magazine, has been able to cast out the positive "first impression" that ISIS desired. The monthly magazine is well put together and tries to appeal to the Western youth. Indeed, Dabiq articles are written in perfect English, contain many beautiful, colored images, and display glorious-looking fighters on top of Toyota trucks. ${ }^{53}$ Through Dabiq and various SNSs, ISIS uses the World Wide Web and the deep web-when the content on the World Wide Web cannot be easily found by standard search engines ${ }^{54}$-to promote jihad, glorify the caliphate, and promise the rewards from Allah (e.g., the afterlife, with its virgins and servants, as well as the peaceful setting with waterfalls and lounging

51 Stern, "Militant Groups: Beneath Bombast and Bombs."

52 Xu Zhang and Lea Hellmueller, "Transnational Media Coverage of the ISIS Threat: A Global Perspective?" International Journal of Communication 10 (2016): 766-785.

53 Matthew Mosk, Brian Ross, and Alex Hosenball, "US Officials Ask How ISIS Got So Many Toyota Trucks," ABC News, October 6, 2015, https://abcnews.go.com/ International/us-officials-isis-toyota-trucks/story?id=34266539 (April 6, 2017).

54 Mhamed Zineddine, "Search Engines Crawling Process Optimization: A Webserver Approach," Internet Research 26, no. 1 (2016): 311-331. 
lions in their visuals). ${ }^{55}$ In the initiating phase, this first contact can also be initiated by the inquisitive online user; here, an individual contacts a person whom he or she thinks is affiliated with ISIS. For those users who have signed up to ISIS-related SNSs, ISIS tweets include links, hashtags, and images. The same content is often tweeted by other users' twitter accounts. ${ }^{56}$

Writing for The Times of India, Hafeez explains how Arif Majeed, then 23year-old in 2014, initiated contact with an ISIS recruiter on an internet chat room. ${ }^{57}$ As Hafeez continues, Arif Majeed "told interrogators that his indoctrination began after he visited an internet chat room. He was inspired to join the terrorist group and given the phone number of a person, whose men picked him up from Mosul in Iraq." ${ }^{\prime 8}$ Such impressionable youth often use SNSs or chat rooms to open communication. Hence, the better the recruiter's first impression, the higher the number of possible future ISIS brothers and sisters. In order to be successful, the recruiter must exhibit charisma.

\section{Experimenting}

Experimenting is the second stage. This stage emerges after the recruiter's first impression is made and the interactants decide to pursue communication further. Once contact with a recruiter has begun, the potential recruit wants to know more about the cause. Often, many questions will be asked (from both sides) during online chats or through SNS posts. As was the case with Arif Majeed, a potential recruit may ask questions in regards to ISIS lifestyle or what it is like to train and die for Allah. ${ }^{59}$ This stage consists mostly of small talk. In regards to the aforementioned Twitter app that ISIS created-The Dawn of Glad Tidings or simply Dawn-countless users can sign up for the app (on the internet or on their smartphones). When a user downloads the app, ISIS immediately asks some personal questions. ${ }^{60}$ This is a reflection of the experimenting phase right there.

During this information-gathering phase, ISIS recruiters tend to paint a picturesque lifestyle of the jihadist cause and all that it has to offer. They tell the possible recruits anything and everything they want to hear in order to gain their attention and support. For example, a recruiter increases positivity during interpersonal dialogue by exaggerating the praise and acceptance that one will find after joining ISIS ranks (because of the commitment to Allah). They may also increase positivity by promising love, sister or brotherhood, and compensation.

55 Harry E. Wedeck and Wade Baskin, Dictionary of Pagan Religions (New York: Philosophical Library, 2015).

56 Berger, "How ISIS Games Twitter."

57 Mateen Hafeez, "Radicalized on Net Chat Room, Given Mosul Contact: ISIS Man," The Times of India, November 30, 2014, p. A1.

58 Hafeez, "Radicalized on Net Chat Room," p. A1.

59 Hafeez, "Radicalized on Net Chat Room."

60 Berger, "How ISIS Games Twitter." 
Dabiq clearly describes how ISIS has an astronomical amount of material wealth: in addition to building five-star hotels in Mosul, the organization gives a salary and a villa with a pool to committed mujahedin. Lastly, Dabiq explains how ISIS offers new recruits the possibility of exerting power over others and even sadism in the name of Allah. ${ }^{61}$

During the experimenting phase, people evaluate whether or not they should progress with the relationship. According to Driscoll, a woman who went undercover online was contacted by an ISIS fighter whose goal was to recruit her. He repeatedly showered her with compliments and claimed that "when you get here, you'll be treated like a princess." 62 By inculcating such ideas into the minds of potentially new recruits, the ISIS radicalizer can portray a paradisiacal lifestyle for successful martyrs and, as a result, can easily influence them to move into the next phase. Not only do they advertise the ideal life; they also depict the afterlife as a bliss in Janna (heavenly garden). ${ }^{63}$

\section{Intensifying}

During the intensifying phase, ISIS recruiters have already solidified contact with people through SNSs or internet chat rooms. Put another way, ISIS has now developed a comfortable dialogue in which they are beginning to form what seems to be a long-lasting relationship. Skype is another common tool that is of utmost importance in this phase because the people involved are now willing to expose themselves visually; this proves that they have progressed to a phase in which they are now feeling more relaxed and are sharing more personal information such as hurtful experiences. ${ }^{64}$ An example is Abdelaziz Kuwan, a teenager from Bahrain, who made the decision to join ISIS in 2014 after spending months interacting via Skype with "some of the brothers" in Syria. ${ }^{65}$ What this anecdote also demonstrates is that, at this stage, interactants are no longer engaging in small talk, but are becoming more serious. ISIS feeds people with false promises during this information exchange in order to promote a positive experience. These recruiters prey on the individual's insecurities and needs, using the disclosure of information in order to manipulate the person.

At this point, ISIS recruiters are strongly reassuring the individual to join their organization and their relationships are becoming more intimate in nature. Abdelaziz was encouraged to travel to Syria to join the fight. He managed to con-

61 Heather Saul, "ISIS Opens 262-room Luxury Hotel in Mosul," Independent, May 6, 2015, p. A1.

62 Margarette Driscoll, "My ISIS Boyfriend: A Reporter's Undercover Life with a Terrorist," New York Post, March 7, 2015, p. A1.

63 Jonathan Matusitz, Symbolism in Terrorism: Motivation, Communication, and Behavior (Lanham, MD: Rowman \& Littlefield, 2014).

64 Joshua R. Pederson and Rachel M. McLaren, "Managing Information Following Hurtful Experiences: How Personal Network Members Negotiate Private Information," Journal of Social and Personal Relationships 33, no. 7 (2015): 961-983.

65 Weiss and Hassan, ISIS: Inside the Army of Terror. 
vince his mother to give his passport back. ${ }^{66}$ In this stage, females are also prone to engaging in a "romantic type" relationship online with an ISIS member-a phenomenon called "love jihad" 67 -which facilitates the advancement to the last two stages: the integrating and bonding stages. At the same time, recruiters avoid discussing the horrors and potential risks that many face after choosing to join ISIS. Most women are reeled in by the communication about acceptance, love, and praise. However, like most recruits, they are left in the dark regarding their actual rights, living arrangements, and lack of freedom they will face after traveling to Syria or Iraq. ${ }^{68}$ The intensifying stage is important to the recruitment process because it enables ISIS recruiters to manipulate individuals into believing that their troubles will be gone once they have joined the organization.

After researching many articles about these ISIS recruiters, it was obvious that many ISIS recruitment methods have similar patterns of answers and shooting down of any negativity (while replacing the negative concerns with positive encouragement). ISIS recruiters use encouragement to persuade the recruit e.g. by uttering short and simple, but convincing statements such as "Many people make this journey every day," "It's not the first time nations have plotted against the believers," "Go to Sham (Syria) for it is the best of Allah's lands on earth," and "It is necessary to live under the caliphate." ${ }^{69}$ Recruiters have even encouraged curious online users to have a conversation with their loved ones to see where they stand and make a possible attempt to recruit them to come along with them. In other instances, recruiters have also managed to convince youth to disappear so as to avoid detection or arrest. Young Western women, in particular, have been at risk. This was the case with three girls who disappeared from the United Kingdom and were found to have traveled to Turkey in order to cross the Syrian border. They had been persuaded to join the cause as a result of months of online interaction with ISIS. ${ }^{70}$

\section{Integrating}

In this context, integrating is the successful recruitment itself, whereby new recruits emigrate to Syria or Iraq to join ISIS. Once recruited, individuals begin to identify themselves as part of the jihadist cause. Through numerous interactions with ISIS on the ground, they begin to identify as "we" or "us" and associate with the terrorist group. In the ISIS environment, integrating implies an "us vs. them" orientation. Both verbal and physical interactions have now become much more

66 Pederson and McLaren, "Managing Information Following Hurtful Experiences."

67 Kishalaya Mukhopadhay, "Queering the Narrative: Can the Subaltern Sex Speak?" Economic \& Political Weekly 51, no. 2 (2016): 20-23.

68 Zainab Salbi, "Rape Survivor Who Escaped ISIS Discusses Torture She Was Subjected to," The New York Times, June 23, 2015, p. A1.

69 Tom Whitehead, "Secret Cell of British Muslim Women Encouraging Others to Join Islamic State Exposed," The Telegraph, November 23, 2015, p. A1.

70 Josh Halliday, Aisha Gani, and Vikram Dodd, "UK Police Launch Hunt for London Schoolgirls Feared to Have Fled to Syria," The Guardian, February 20, 2015, p. A1. 
intimate. New recruits have moved from being their own individuals to being ISIS members - a process called depluralization. ${ }^{71}$ Depluralization is a process whereby a person relinquishes his or her formal "self" so as to assume a new "self." In essence, joining ISIS requires integrating a new group-affiliated "self" by adopting the entire group's philosophy and blending in with the other members. ${ }^{72}$ When integrating, the recruiter is actively planning out the new recruits' mission and place within an elitist Muslim brotherhood.

\section{Bonding}

The last stage of relationship escalation is bonding, whereby a close relationship has been formed and individuals are fully committed to fighting with ISIS and honoring the allegiance they have sworn to Abu-Bakr al-Baghdadi, the current ISIS leader. ${ }^{73}$ Now, ISIS recruits are full-fledged members of the terrorist organization. An important aspect of this phase is that individuals have now identified with ISIS publicly. They upload videos of their new ISIS selves online or post tweets about their jihadist lives on SNSs. ${ }^{74}$ Members also have symbolic cues they use to show their support such as standing with their index finger pointed upwards to show their solidarity with caliphate fighters. Essentially, this nonverbal gesture symbolizes the bonding between ISIS and Allah - reflecting the following message: we have been called by Allah to kill anyone until the worldwide caliphate is established. ${ }^{75}$

In order to prove their total loyalty to ISIS, members must also be "hazed" into the terrorist group through a type of public initiation. To be more precise, they have to engage in a public action of killing the enemy - even if it means killing one's own mother. In January 2016, a young ISIS recruit killed his own mother who was not supportive of his cause. She was accused of apostasy after her son reported her to senior ISIS members. The woman's son, 20-year-old Ali Saqr al-Qasem, was persuaded to execute her with his own hands. After demonstrating his lethal commitment, his loyalty to ISIS was unquestionable, allowing the bonding stage to seal. ${ }^{76}$ At the bonding stage, these full-fledged ISIS members will attempt to influence others to join them and may even become recruiters themselves. On the other hand, it is unlikely that the average ISIS member

71 Margaret Singer with Janja Lalich, Cults in Our Midst: The Hidden Menace in Our Everyday Lives (San Francisco: Jossey-Bass, 1995).

72 Barbara Franz, "Popjihadism: Why Young European Muslims Are Joining the Islamic State," Mediterranean Quarterly 26, no. 2 (2015): 5-20.

73 McCabe, "A Strategy for the ISIS Foreign Fighter Threat."

74 Diana Secara, "The Role of Social Networks in the Work of Terrorist Groups. The Case of ISIS and Al-Qaeda," Research and Science Today, Summlement 3 (2015): 77-83.

75 Orlando Crowcroft, "ISIS: What is the Story Behind the Islamic State One-fingered Salute?" International Business Times, June 15, 2015, p. A1.

76 John Hall, "ISIS Militant Ali Saqr al-Qasem Publicly Executes Own Mother in Raqqa after Accusing Her of 'Apostasy',"' Independent, January 8, 2016, p. A1. 
will part from the cause. This final phase seals the recruitment process with the end game resulting in a new supporter and fighter for the Islamic State.

\section{Discussion and Future Directions}

What this analysis has demonstrated is that ISIS can successfully recruit many individuals around the world-particularly male and female youth-thanks to stage-by-stage relational development through internet chat rooms and social network sites (SNSs) like Twitter. By the same token, we also believe that, should ISIS not use internet chat rooms and SNSs, and if ISIS were not following those stages of relationship escalation, their recruitment process would not be as efficient. From this vantage point, the five relationship escalation stages allow us to see how relationships are formed and make it possible for us to understand the complexity of interpersonal interactions (both offline and online).

Overall, upon examining ISIS recruitment, we observed a trend of positive assurances made by terrorist recruiters in order to convince individuals to join the jihadist cause. According to Matusitz, "one method for solving a relationship crisis is to either enhance positive feelings or reduce certain negative feelings to make the other party content during the dialogue."77 By enhancing positivity, ISIS can make the recruit comfortable and vulnerable to manipulation. The objective of ISIS is to exterminate infidels and establish a caliphate around the world. So, in every phase of recruitment, positivity and encouragement are used as a form of persuasion. This terrorist organization has proven to excel in this process. It is important that we understand how ISIS employs these stages so that we can better help victims and put a stop to its widespread recruitment.

For future research, it may be interesting to examine two additional aspects of ISIS's recruitment. First, with the European migrant crisis currently happening, in which over one million asylum-seekers have fled Muslim nations like Syria, Iraq, and Afghanistan as well as war-torn countries from Africa, ${ }^{78}$ would ISIS be even more successful in its recruitment of would-be jihadists by infiltrating refugee camps? British Prime Minister David Cameron has warned us that "one in fifty Syrian refugees in Europe could be an ISIS jihadist." 79 Under these circumstances, it would be useful to compare today's ISIS's recruitment through SNS with the organization's infiltration of refugee camps. The objective would be to determine which of the two techniques is more efficient.

Second, an important question looms large: although studies and articles have confirmed that many ISIS recruits online are male and female youths, are young potential recruits all that naïve, lonely, and disaffected? It is true that many things are taken into account in order to make a good first impression -

77 Matusitz, Terrorism and Communication: A Critical Introduction, quote on p. 365.

78 Tim Arango, "Disappointed with Europe, Thousands of Iraqi Migrants Return Home," The New York Times, February 4, 2016, p. A1.

79 Cited in Alexandra Sims, " 1 in 50 Syrian Refugees in Europe Could be an ISIS Jihadist, Minister Warns David Cameron," Independent, September 15, 2015, p. A1. 
from charismatic communication to appealing visuals and body language. Yet, it is also a known fact that a certain number of ISIS youth are highly educated individuals, with college degrees, and in-depth knowledge of science and engineering. ${ }^{80}$ Hence, what are other factors that motivate youth to join ISIS? The answers to such questions need to be ascertained through solid research.

It is the authors' hope that this analysis of ISIS's recruitment, through the theory of relational development, has enlightened readers on how effective online social media can help a terrorist organization to be so successful at recruiting. This analysis can help others understand how easy it can be to manipulate individuals into joining a terrorist group simply through SNSs. Relational development was applied to a subject that had not been examined from such theoretical perspective before, making it a positive addition to the communication discipline at large. Both scholars and practitioners alike can now regard the ISIS recruitment process from a different angle.

\section{About the authors}

Sarah Ponder is a research assistant in the Nicholson School of Communication at the University of Central Florida. Her academic interests include terrorism studies, conflict studies, and intercultural communication.

Jonathan Matusitz, Ph.D., is an Associate Professor in the Nicholson School of Communication at the University of Central Florida. His academic interests include terrorism studies, communication \& technology, and intercultural communication. Please address correspondence to Jonathan Matusitz at University of Central Florida at Seminole State College, Partnership Center (\#UP 3009), 100

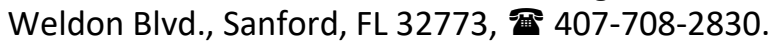

E-mail: matusitz@gmail.com.

80 Maajid Nawaz, "The Education of “Jihadi John," The New York Times, March 3, 2015, p. A1. 